\title{
Entrepreneurship: Geographies and Social Context
}

\author{
Elaine Da Silveira Leite and Natalia Maximo e Melo \\ Federal University of São Carlos, \\ Brazil
}

\section{Introduction}

This paper presents some researches' results conducted by the authors between 2006 and 2010. It aims to analyze the process in which entrepreneurship rose in Brazil, focus on SEBRAE (Brazilian Service of Support for Micro and Small Enterprises). It is an institution whose origin is associated with government policies, principally, between 1970 and 1980 .

Since the 1970s, the media, newspaper and best-seller books have been reported the entrepreneurship as an economic practice that promotes national economy development. According to Swedberg (2001), entrepreneurship movement spread around the world without regard to differences in the countries, their mindset and values related to economic and social activities.

There are many social aspects that favored the rise of entrepreneurship in several countries such as the revival of small and medium enterprises (SMEs), changes in political and economic ideology after Thatcher and Reagan government (1979-1980) and the passage of Keynesianism, which promoted pro-market policies. The unemployment, which has haunted this period, also encouraged the perception that new businesses could create jobs in scale (Swedberg, 2001).

In the U.S., entrepreneurship was already discussed since the 1950s. However, the researches about the SMEs were not directly linked to the entrepreneurship; it focuses on the SMEs as creator of employment. SEBRAE is the main institution responsible for conducting quantitative research that addressed the topic of micro and small enterprises in Brazil. These surveys have been served as empirical material for academic studies.

Serva (2002) realized a literature review and pointed out that the entrepreneurship is often puzzled with small enterprises issues in Brazil. The author has mapped entrepreneurship's courses in Brazilian universities. As a result, it was noted that by the 1980's, the first business courses deal with companies issues, and after, they were renamed to emphasize what is called entrepreneurship.

In this way, Brazilian academic researchers about entrepreneurship also focus on small and micro enterprises. These researches aim to evaluate the entrepreneurial businessmen contrasting their actions and performances established by the academic literature about entrepreneurship. Other studies emphasize the introduction of technology in micro and 
small enterprises in order to achieve greater competitiveness. There is also another perspective that understands entrepreneurship as a set of strategies such as creation, growth and survival of micro and small enterprises. An additional group of authors were concerned with entrepreneurship as a discipline; they were dedicated to analyze education programs at universities and the rise of other institutions that promote the entrepreneurship.

Finally, there are also academics works that adhere to the peculiarities of projects driven by ethnic and minority groups such as women. Consequently, there are various social actors that make reference to entrepreneurship as a way to tackle the economic problems presented in some developing country. They are researchers, consultants, journalists, etc. This scenario led us to investigate the origin of this phenomenon in Brazil. After all, if the entrepreneurship had no stimulus, how was it been developed in Brazil?

The process that stimulates the entrepreneurship also is concerned symbolically in promoting national economic growth. To comprehend the entrepreneurship dynamic is important to be familiar with the small enterprises progress issues. So, it is also important to understand the Brazilian economy scenario since 1970s.

\section{Theories of economic development and small enterprises issues}

In the 1970s, the academic literature suggested that the debate around national development was the transition from a rural economy to an urban and industrial economy. The national policies points were the industrialization process and new forms of labor occupation that emerged in that scenario (Abramo and Miller, 1995).

Diniz and Boschi (1978) present that, in the 1930s, the literature take for granted the industrial irrelevance in the Brazilian economy sphere, as well as, the political corporate elite insignificance that marked that decade. The authors traced some considerations about small enterprises spread that formed a single market from wage labor. Diniz and Boschi explained that there were large numbers of small enterprises composing the industrial sector, but the large enterprise already formed a solid business elite.

In spite of this, the academic literature until the 1970s focused on analysis that related capital versus labor, in which the intermediate layers as small enterprises owners had no place in national economic development or the small enterprises were consider merely to illustrate the corporate elite as having a political power (Wanderley, 1999).

Brazil, when compared with companies from developed countries, appeared as a pattern of "traditional" companies, because they were related to family management. Within the modernization, Brazilian companies should go through a rational process of management. Therefore, Cardoso (1964) studied the Brazilian economy modernization, regarding not only the transition from agrarian to industrial economy, but also the internal transformations that occurred in Brazilian industry.

Cardoso's effort expressed the perception that symbolically involved Brazilian companies in 1960s and 1970s. The idea that family businesses predominate in Brazil and Latin America was also reproduced in the academic literature. Lipset (2000), for example, established an evaluation between North-American and Latin American literature, as a result, it pointed out that there were differences among the cultures related to the organizational level and the companies' management. 
In Latin America, there is not much separation between management and other administrative activities, the bureaucratic norms are weak, the personal characteristics are more valued than the organizational skills, and the managers are recruited based on family relationships. It is interest to observe that national and foreign authors believed that traditional companies were not a good business model. It justified their exclusion in relation to incentive and support programs, both by public policies and private bank.

Until the 1970s, the illustrative factor of national modernity was concentrated in large companies. It was in large companies that new technologies and better jobs were found in that period. The small enterprises were dependent on big companies. Considered as large thumbnails, small enterprises would present a general tendency to become great, otherwise, it would tend to fail.

Even in the 1970s, the academic studies were developed based on the informal economy notion, in which it was defined as an easy way to get into businesses. The ownership was individual or controlled by families, the production was based on small-scale, the technology was adapted, and the markets were competitive and unregulated. In this economic sphere that small enterprises were located in the national economy.

The economic activities, that did not fit the rhetoric capital versus labor, did not emerge in the literature or appear classified as belonging to the informal economy were activities considered transitional to the wage labor. They were temporary activities realized by migrants that came from rural places or other countries. That is, activities related to the lack of job. By the way, it was stated that these activities would tend to come to an end or to reduce as long as the industrialization move forward in Brazil.

In the 1970s, not all banks employed a definition to describe the company size (small, medium and large - but not micro enterprises at that time). This frame served the purposes of defining the credit market to businesses. In that moment, there was no goverment legislation to define the tax laws. In this period, it appears the CEBRAE (Center for Management Assistance to Small and Medium Enterprises), the first government entity to support small and medium enterprises, in which the main goal was to support the credit orientation.

According to the IBGE (Brazilian Institute of Geography and Statistics), it was in the 1980s, that Brazil had witnessed a slowdown of economic growth accompanied by an increase unemployment level. In this moment, small enterprises became an alternative occupation and it brought the first initiatives that favored the rise of micro and small enterprises. As a result, it become institutionalized the company categories by their size that improve incentives and tax laws.

From 1990's, small enterprises issues reached the media and SEBRAE (Brazilian Service to Support Micro and Small Enterprises) replaced the CEBRAE, which ceased to exist in 1989s. These were two important factors to the entrepreneurship institutionalization.

It also marked the history of small enterprises institutionalization as company category and also the advances in some political system, for example, unions, associations and the emergence of discussions forum. In summary, the initiatives that have institutionalized small enterprises in Brazil: First Small Enterprises Law (1984); Inclusion of SME's in the Federal Constitution (1988); Establishment of credit lines coming from the public sector; 
Law n. 9317, which established special tax by company size (1996); Law n. 9841, which established the status of SME's (1999); Establishment of a SME's Permanent Forum (1999).

The SME's was considered a kind of traditional company, but it survived from the imperatives of capital. Today, SME's formed an economic niche with potential great to stimulate modernization and economic development in Brazil.

\section{The rise of SEBRAE}

The Brazilian economic process that incorporated small enterprises as part of the national economic development agenda is essential to comprehend the rise of Cebrae, an institution that is the principal proponent of entrepreneurship nowadays in Brazil.

The CEBRAE, an institution that emerged in the 1970s, as a state apparatus, gained preeminence when the national economic policies established by a dictatorial government were seeking to promote industrialization. The rise of CEBRAE/SEBRAE is the main focus of this paper, because it was consider one of the principal institutions recognized to stimulate the entrepreneurship in Brazil. This institution has gone through several historical phases as the economic policies of governments have changed, but it was always linked to the prospect of national development.

CEBRAE was constituted as a government structure from 1972 to 1990. While the organization was linked to the State, it operated mainly credit programs focus on credit concession and managerial assistance through consulting activities. The credit was granted by BNDE (National Bank for Economic Development) and Regional Development Banks, administered by the government.

This structure was changed in 1990, when CEBRAE was transformed into an autonomous social service institution. In other words, it became part of parastatal organizations and its name was changed to SEBRAE. Throughout its history, this institution has operated credit policies for industry, but as the national development policy changes to other sectors, SEBRAE needed to ensure its position, so it was necessary to SEBRAE accompany the scenario changes. "SEBRAE came into being in 1972 as result of a pioneer initiative of many institutions that encourage entrepreneurship in the country. $1^{\prime \prime}$

These organizational changes followed the restructuring of companies trend in the 1990s, requiring that SEBRAE programs must be changed. In this point of view, SEBRAE introduced the entrepreneurship program and it also transformed the old programs into the entrepreneurial perspectives.

Therefore, entrepreneurship became associated with the historic of the institution and it is also part of the national economic scenario, in which large companies went through restructuring process, because the levels of unemployment rates were increasing in that period. The small enterprises promotion had the entrepreneurship theme as a slogan that appeared associated to the national development program in the 1990s.

\footnotetext{
1 Information taken from:

http://www.sebrae.com.br/customizado/sebrae/institucional/sebrae-in-english. June, 2011.
} 
From the 1990s, SEBRAE introduced a program to encourage entrepreneurship that is linked to UN (United Nations Organization). This program, Empretec, is applied in several countries to stimulate economic development from individual behavior. And, it is the base for all other entrepreneurship programs elaborated by SEBRAE. The Empretec will be the subject of the next chapter.

\section{Entrepreneurship and Empretec}

Entrepreneurship was a conventional subject from economic theory. Schumpeter (1982) is considered the classical theorist of entrepreneurship. He suggests that the connection between innovation and business leadership generates economic development, theoretically, it contrasts with the neoclassical perspective.

Schumpeter has two articles about entrepreneurship. The first is the second chapter of his book "Theory of Economic Development" and the second article is a paper prepared for a Handbook in 1928. The first is the his best known work. In the first edition of his book, Schumpeter presented a more heroic entrepreneur concept and its activities. He also affirms that some people present characteristics to be an entrepreneur while others do not have the same competence.

In addition, there is a recent psychological bias known as behaviorism, in which the characteristic of the entrepreneur goes beyond the creative and innovative skills. For the behaviorist, the entrepreneur is also the man who organizes the firm and increases its productive capacity. McClelland, the principal representative of the behaviorists, sustains the notion that it is through these entrepreneur activities that is possible to achieve economic development. From this perspective, individuals frequently tend to seek for improvement and individual progress (McClelland, 1961).

This perspective stresses a combination between economic variables such as technology, capital, etc. and psychological attributes. The entrepreneur pointed out by Schumpeter is no longer an economic function located in a given time into the economic cycle, but now, the behaviorist perspective presented that the entrepreneur becomes a kind of human being.

In this sense, the small enterprises have become embedded in the economic development project and the entrepreneur became an important economic actor that needs to be stimulated to reach the success. This new circumstances could be explained by the concepts of entrepreneurship and entrepreneurs that have been studied and motivated by academic theories.

In general, the notion of entrepreneurship began to be massively spread to the global society from the 60's, especially after the UN (United Nations Organization) published as unsatisfactory some results about financial incentives given to developing countries. Therefore, UN has been relied on surveys conducted by behavioral psychologists, especially Dr. David McClelland that also acts together with USAID (United States Agengy for International Development), in which pointed out that individuals who are motivated have better performances.

The behavioral research conducted by McClelland was used by MSI (Management Systems International) consulting firm that elaborated a methodology for behavioral training. This 
coaching is composed of behavioral dynamics and it is applied in many countries, especially in the developing ones. This program was named Empretec. In Brazil, it is applied by SEBRAE since 1993.

The Empretec methodology (developed by David McClelland at Harvard University) is based on the finding that everyone has an inner motivation to improve. This "motive for action" is divided into three motivational categories: achievement, affiliation, and power ${ }^{2}$.

There are 10 Personal Entrepreneurial Competencies, which form the basis of the Empretec Training Workshop. The 10 competencies are: Opportunity-seeking and initiative, Persistence, Fulfilling of commitments, Demand for quality and efficiency, Calculated risktaking, Goal-setting, Information-seeking, Systematic planning and monitoring, Persuasion and networking, Independence and self-confidence.

Empretec is presented by UNCTAD as a program that aim to promote small and medium enterprises as well as business skills. It can be applied to different people from businessmen to government officials. The Empretec Foundation in Argentina, the entity that applies the program in the country, discloses that the Empretec was created to foster entrepreneurship in developing countries.

The Empretec program should be requested to the UNCTAD to be implemented in the countries. The entity is responsible to evaluate and to select what local organizations could apply the program. After, the methodology be transferred to the partner institutions or Empretec national centers, it is expected that the next workshops would be implemented by the local team, but within the UNCTAD Program framework.

Although, there is no other entrepreneurship program that replaces the Empretec. By the way, it is possible to find some alternatives programs that stimulate entrepreneurship skills. The Empretec suffers from high competition. The Universities have been developed entrepreneurship programs and consulting firms that are interest to enter in the educational entrepreneurship market.

In 1991, the Empretec was developed by the State Bank of Rio Grande do Sul (Banresul) in Brazil. In 1993, it was implemented by SEBRAE, today there is about 550 locations around the country. In UNCTAD's report, Brazil has been highlighted to conduct significant numbers of seminars about the topic. Moreover, Brazil also held international events every year.

The Empretec plays a central role in the activities of SEBRAE. The other courses offered by SEBRAE are also shaped by Empretec content, for example, "Know how to be an endeavor" and "Learning to endeavor". The material distributed also aggregated the entrepreneur subject, but focus on different audiences.

SEBRAE also incorporated the entrepreneurship into its organizational structure, programs and transformed the Education Unit in the Education Unit and Development of

${ }^{2}$ Source UNCTAD, 2011. 
Entrepreneurial Culture (EUCD). Some SEBRAE instructors also helped to implement the entrepreneurship program in other countries like Romania, Jordan, northern Italy, Angola, Mozambique, etc.

Empretec is the basis for the entrepreneurship programs developed by SEBRAE. In this sense, it is important to understand how Empretec training is been conducted and what means entrepreneurship nowadays. These issues will be elaborated in the next chapter.

\section{The entrepreneurship by Empretec}

Having started in 1988, Empretec is now operating in 10 countries (Argentina, Brazil, Chile, Colombia, Ghana, Morocco, Nigeria, Uruguay, Venezuela and Zimbabwe). Well over 10,000 "empretecos" (one third of them women) have participated in ED workshops and related follow-up services ${ }^{3}$.

Empretec is a program that provides training in entrepreneurship for small and medium enterprises in developing countries. Its activities involve the delivery of motivational and technical seminars, the provision of advisory services and the development of national and international networks serving the needs of entrepreneurs ${ }^{4}$.

The Empretec seminars usually have six days trainning. Over 100 thousand people have taken the Empretec in Brazil ${ }^{5}$. The seminar focuses on entrepreneurs or people who decided to open their own business. Initiatives in seeking opportunities, aptitude to take risks, persistence and objectivity in goal setting are some of the behaviors focused on the course.

Programmers can also help to orient educators and the educational curricula to the relevance of entrepreneurship development. Vocational schools and university programmers, especially in such fields as business and engineering, can encourage students to apply their skills by starting new businesses and they can assist them in doing so. At the primary and secondary levels, it may be most appropriate to focus on developing entrepreneurial attitudes ${ }^{6}$.

The seminar has different activities such as dynamics interaction and lectures with professors and it also is supported by fictional stories as motivational tool. It is possible found the entrepreneur in different activities, that is, there are several reasons and means to be entrepreneur, but the final result is the individual ability to become an entrepreneur that is measured by its economic success not by social context.

These fictional stories symbolic have the capacity to change the perception about the social world, emphasizing the existence of different social actors that figure as an entrepreneur,

\footnotetext{
${ }^{3}$ Entrepreneurship Development In:http://www.undp.mn/publications/essentials/document/english/EssentialsEntrepreneurship2.pd f. UNCTAD. P. 08.

${ }^{4}$ Ibid.

${ }^{5}$ Ibid.

${ }^{6}$ Entrepreneurship Development In:http://www.undp.mn/publications/essentials/document/english/EssentialsEntrepreneurship2.pd f. UNCTAD. P. 07
} 
for example, housewife and unemployed. The types of entrepreneurs (housewife and unemployed) present different ways to carry out economic activity, such as, reasons (opportunity, necessity) and means (underutilized resources, technological competence).

Thus, it evidences that the entrepreneurship content spread by Empretec organizes the relationship of individuals between themselves and the world, performing individual qualities perceptions. What makes people from different social classes and activities be identified (and identify themselves) as entrepreneurs is the characteristics shared by the same social meanings setting, even if they lead failure or success.

\section{Final considerations}

Currently, there are a lot of advertising, publishing books and magazines, TV shows and universities that spread the entrepreneurship; what makes the term and the ideas that it carries embedness in social thoughts. This dynamic makes the term seems a natural characteristic of individual.

The Empretec training, as well as events, lectures, media, success stories, which are in vogue by the 2000s, aims to spread a belief that ensure adherence to voluntary activities of individuals capitalist as well as the social construction of an new ethic that recognized as "good" or "fair" the entrepreneurship. And so, it produces a cultural change that alters practices and perceptions about the economic world and social development in Brazil.

Entrepreneurship, as a way of reframing the small enterprises and labor world, values informal activities, people that was excluded from business world and banned from formal employment. Even if the objective conditions of the social structure do not change deeply, at least, it changes how they are socially viewed, that is, the excluded individuals move to the positive pole, or at least, the individual have the option to transform his economic condition.

In Brazil, SEBRAE is an institution that expresses the social process and condenses the new social values that allows entrepreneurship be developed in Brazil. SEBRAE via entrepreneurship have been aggregated a public which had no support and social legitimacy to become an entrepreneur.

Instead of a definitive conclusion, this study allows us to raise questions about the economic development in Brazil. Does it possible understand the entrepreneur behavior as an issue that expresses national economic development? Now, within the entrepreneurship movement, is the individual economic success a single factor in the country?

\section{References}

Abramo, Laís e Montero, Cecília. A sociologia do Trabalho na América Latina: paradigmas Teóricos e Paradigmas produtivos. BIB, Rio de Janeiro, no.40, 20 semestre 1995, pp. 65-83.

Addis, K; Gomes, E. Corporativismo, liberalização e democratização: um estudo a partir dos serviços do Sistema S. In: ABREU, A. A. (org). A democratização no Brasil atores e contextos. Rio de Janeiro: FGV, 2006. 
Aldrich, H.E. “Entrepreneurship.” In: SWEDBERG, Richard; SMELSER, Neil (org), Handbook of Economic Sociology. Princeton: Princeton University Press and Russell Sage Foundation, 2004.

Boltanski, L; Chiapello, E. El Nuevo Espíritu del Capitalismo. In: Cuestiones de Antagonismo, Akal: Madrid, 2002.

Bourdieu, Pierre. O Poder Simbólico. Tradução de Fernando Tomaz. Lisboa Difel, 1989. . O campo econômico. In: Política e Sociedade.n.6, abril de 2005.

Cardoso, F. H. Empresário industrial e desenvolvimento econômico no Brasil. São Paulo: Difusão Européia do Livro, 1972.

Cassiolato, J.E.; Lastres, H.M.M. O foco em arranjos produtivos e inovativos locais de micro e pequenas empresas. In: Lastres, H. M. M. (Org.); Cassiolato, J. E. (Org.); Maciel, M. L. (Org.). Pequena empresa: cooperação e desenvolvimento local. Rio de Janeiro: Relume Dumará, 2003.

Colbari, A. A retórica do empreendedorismo e a formação para o trabalho na sociedade brasileira, VIII Congresso Luso-Afro-Brasileiro de Ciências Sociais, Universidade de Coimbra, 16 a 18 de setembro de 2004.

. Trabalho, auto-emprego e pequeno negócio: reconfigurando as estratégias de capacitação profissional e de desenvolvimento local. XXX Encontro Anual da Anpocs, 2006.

Cypriano, C. A. Pequena empresa, desenvolvimento social e ação institucionalizadora do Sebrae. Tese de Doutorado, Escola de Administração, UFBA, 2004.

Diniz, Eli; Boschi, Renato R. Empresariado nacional e Estado no Brasil. Rio de Janeiro: ForenseUniversitária, 1978.

Dornelas, J. C. A. Empreendedorismo: transformando idéias em negócios. Rio de Janeiro: Elsevier, 2001

Fligstein, N. O mercado enquanto política: uma abordagem político-cultural às instituições de mercado. In: Marques, R, Peixoto, João( org). A nova Sociologia Econômica. Oeiras: Celta Editora, 2003

Granovetter, Mark. The Economic Sociology of Firms and Entrepreneurs. In: Swedberg, R.(org.) Entrepreneurship: the social sciense view. New York: The Oxford University Press, 2000.

Grun, Roberto. Em busca da nova pequena burguesia brasileira. Dados, 2000, vol.43, no.

Huczynski, A. Management Gurus: what makes them and how to become one. London and New York: Routledge. 1993

Lipset. Seymour M. Values and Entrepreneurship in the Americas. In: Swedberg, R.(org.) Entrepreneurship: the social sciense view. New York: The Oxford University Press, 2000.

Lopes, Eliana B. M. O SEBRAE e as relações público - privado no Brasil. Dissertação de Mestrado. UNESP/ FCLAR, 2001

López-Ruiz, O.J. Da ética protestante ao ethos empresarial: "capital humano" e " empreendedorismo" como valores sociais. Seminário CEBRAP, Fev/ 2007. Disponível em www.cebrap.org.br. Acessado em 23 de janeiro de 2008.

Martinelli, Alberto. "Entrepreneurship and Management". In Smelser, Neil and Swedberg, Richard (editors). The Handbook of Economic Sociology. Princeton: Princeton University Press.1994.

McClelland, David C.. The achieving society. New York: Free Press, 1967 
Montaño, C. Microempresa na era da Globalização uma abordagem histórico-crítica. 2 ed. São Paulo: Cortez, 2001

Noronha,E.G. "Informal" Ilegal, Injusto: percepções do mercado de trabalho no Brasil. Revista Brasileira de Ciências Sociais. Nov. 2003 Vol. 20, nº 53.

Portes, A. "The informal economy and its paradoxes", in N. Smelser e R. Swedberg (orgs), The handbook of economic sociology, Princeton, Princeton University Press, 1996

Polanyi, K. The economy as instited process. In: The sociology of economic life. Granovetter, Mark; Swedberg, Richard (orgs). Boulder: Westview Press, 1992

Ralio, Vanise R. Z. Consultoria e Cooperativismo: cooperativa de consultores e espaço de consultoria brasileiro. Dissertação Mestrado em Engenharia de Produção : UFSCar: 2007

Serva, Mauricio. Contribuição da sociologia econômica à teoria das organizações. Revista Sociedade Estado. Vol. VXVII (1). Brasília, 2002

Smelser, N. e R. Swedberg. The sociological perspective on the economy in: The Handbook of Economic Sociology. Princeton: Princeton University Press. 1994.

Schumpeter, J. A. Teoria do desenvolvimento econômico: uma investigação sobre lucros, capital, crédito, juro e o ciclo econômico. Serie Economistas. São Paulo: Abril Cultural. 1982.

Silva, Nilson Carlos Duarte da. Valorização da formação da cultura empreendedora dentro da universidade. Um estudo de casos: UFSC, UFMG e PUC-Rio. ( dissertação de mestrado - Dep Eng. Produção) São Carlos: UFSCar, 2002.

Souza Neto, Bezamat. Contribuição e Elementos para um Metamodelo Empreendedor Brasileiro: $O$ Empreendedorismo de Necessidade do Virador. [Tese - Universidade Federal do Rio de Janeiro] COPPE, Rio de Janeiro, 2003.

Wanderley, F. Pequenos negócios, industrialização local e redes de relações econômicas: uma revisão bibliográfica em sociologia econômica. BIB, Rio de Janeiro, $\mathrm{n}^{\mathrm{O}} .48,2^{\mathrm{O}}$ semestre de 1999, pp. 15-49

Weber, Max. A Ética Protestante e o Espírito do Capitalismo. São Paulo: Martin Claret, 2001 


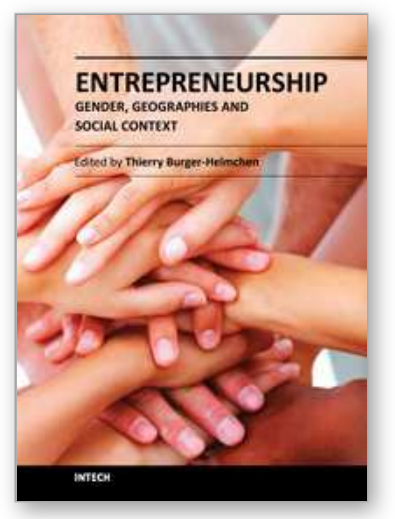

\author{
Entrepreneurship - Gender, Geographies and Social Context \\ Edited by Prof. Thierry Burger-Helmchen
}

ISBN 978-953-51-0206-9

Hard cover, 306 pages

Publisher InTech

Published online 14, March, 2012

Published in print edition March, 2012

Entrepreneurship is a main driver of economic growth and of social dynamics. However, some basic characteristics like the gender of the entrepreneur, the geographical location, or the social context may have a tremendous impact on the possibility to become an entrepreneur, to create a firm and to prosper. This book is a collection of papers written by an array of international authors interested in the question of entrepreneurship from a gender point of view (male vs female entrepreneurship), a geographical point of view (Africa, Europe, America and Latin America, Asia...) or a specific social context point of view (agricultural economy, farming or family business, etc.).

\title{
How to reference
}

In order to correctly reference this scholarly work, feel free to copy and paste the following:

Elaine Da Silveira Leite and Natalia Maximo e Melo (2012). Entrepreneurship: Geographies and Social Context, Entrepreneurship - Gender, Geographies and Social Context, Prof. Thierry Burger-Helmchen (Ed.), ISBN: 978-953-51-0206-9, InTech, Available from: http://www.intechopen.com/books/entrepreneurshipgender-geographies-and-social-context/entrepreneurship-geographies-and-social-context

\section{INTECH}

open science | open minds

\section{InTech Europe}

University Campus STeP Ri Slavka Krautzeka 83/A 51000 Rijeka, Croatia Phone: +385 (51) 770447 Fax: +385 (51) 686166 www.intechopen.com

\section{InTech China}

Unit 405, Office Block, Hotel Equatorial Shanghai No.65, Yan An Road (West), Shanghai, 200040, China 中国上海市延安西路65号上海国际贵都大饭店办公楼 405 单元 Phone: +86-21-62489820

Fax: +86-21-62489821 
(C) 2012 The Author(s). Licensee IntechOpen. This is an open access article distributed under the terms of the Creative Commons Attribution 3.0 License, which permits unrestricted use, distribution, and reproduction in any medium, provided the original work is properly cited. 